\title{
Real-Time Tracking and In Vivo Visualization of $\beta$-Galactosidase Activity in Colorectal Tumor with a Ratiometric NIR Fluorescent Probe
}

Kaizhi Gu, ${ }^{\dagger, \S}$ Yisheng Xu, ${ }^{\star,}$ Hui Li, ${ }^{\#, \S}$ Zhiqian Guo, ${ }^{*, \dagger}$ Shaojia Zhu, ${ }^{\perp}$ Shiqin Zhu, ${ }^{\dagger}$ Ping Shi, ${ }^{\perp}$ Tony D. James, ${ }^{\Delta}$ He Tian, ${ }^{\dagger}$ and Wei-Hong Zhu* ${ }^{\dagger} \dagger$

${ }^{\dagger}$ Key Laboratory for Advanced Materials and Institute of Fine Chemicals, Shanghai Key Laboratory of Functional Materials Chemistry, School of Chemistry and Molecular Engineering, East China University of Science and Technology, Shanghai 200237, China.

State Key Laboratory of Chemical Engineering, East China University of Science and Technology, Shanghai 200237, China.

\# Department of Radiology, Shanghai Jiao Tong University Affiliated Sixth People's Hospital, Shanghai 200233, China.

${ }^{\perp}$ State Key Laboratory of Bioreactor Engineering, East China University of Science and Technology, Shanghai 200237, China.

${ }^{\Delta}$ Department of Chemistry, University of Bath, Bath BA2 7AY, U.K.

E-mail: whzhu@ecust.edu.cn; guozq@ecust.edu.cn 


\section{Contents}

1. Experimental section...................................................... S3-S6

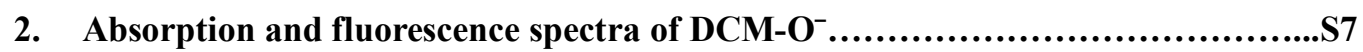

3. Absorption and fluorescence spectra of DCM- $\beta$ gal incubation with $\beta$-gal...........S7

4. Kinetics curve of DCM- $\beta$ gal reaction with $\beta$-gal at $685 \mathrm{~nm}$......................... S8

5. Photophysical properties of DCM- $\beta$ gal, DCM-O ${ }^{-}$, and DCM-OH ..................... S9

6. Enzyme parameters of DCM- $\beta$ gal and $X$-gal...................................S10

7. The detection limit of

DCM- $\beta$ gal..................................................S10

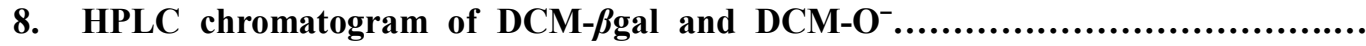
S11

9. ESI-MS spectra characterization of DCM- $\beta$ gal reaction with $\beta$-gal..................S12

10. pH-dependent fluorescence intensity of DCM- $\beta$ gal and DCM-OH.................S13

11. Cytotoxicity of DCM- $\beta$ gal and

DCM-OH...............................................S13

12. Semiquantitative determination of endogenous $\beta$-gal activity in living cells..........S14

13. In vivo imaging of $\beta$-gal activity in tumor-bearing nude mice.........................S15

14. Stereoview crystal structure of $\beta$-gal..............................................

15. Characterization of intermediate compounds and

DCM- $\beta$ gal....................S17-S21 


\section{Experimental section}

\section{Materials and general methods}

Unless special stated, all solvents and chemicals were purchased from commercial suppliers in analytical grade and used without further purification. $\beta$-Galactosidase ( $\beta$-gal) was supplied by J\&K Scientific Ltd. LacZ gene kit and $X$-gal were purchased from Invitrogen Company (San Diego, CA, USA). Avidin- $\beta$-gal was purchased from Sigma-Aldrich. 4-Hydroxybenzaldehyde was purchased from Adamas-beta. The ${ }^{1} \mathrm{H}$ and ${ }^{13} \mathrm{C}$ NMR spectra were recorded on a Bruker AM 400 spectrometer, using TMS as an internal standard. High resolution mass spectrometry data were obtained with a Waters LCT Premier XE spectrometer. Absorption spectra were collected on a Varian Cary 500 spectrophotometer, and fluorescence spectra measurements were performed on a Varian Cary Eclipse fluorescence spectrophotometer. HPLC analysis was performed on an Agilent 1100 series. Life time was measured with Edinburgh Lifespec-Ps spectrofluorometer (FL920). Confocal fluorescence images were taken on confocal laser scanning microscope (CLSM, Nikon A1R/A1). In vivo fluorescence images and three-dimensional (3D) in vivo fluorescence images were measured with a PerkinElmer IVIS Lumina Kinetic Series III imaging system and IVIS Spectrum CT imaging system, respectively.

\section{Synthesis of DCM- $\beta$ gal}

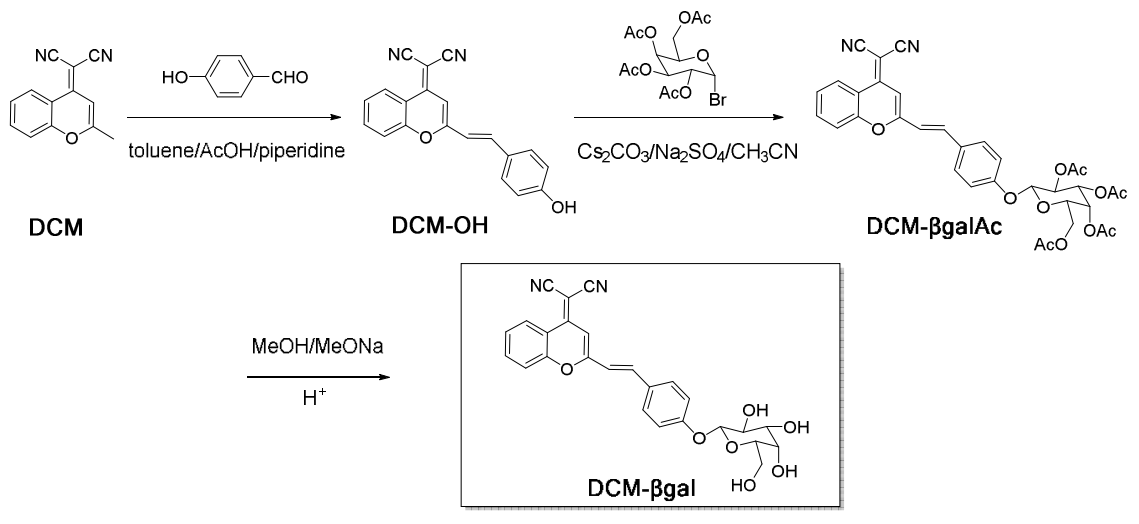

Scheme S1 Synthetic route of DCM- $\beta$ gal

\section{Synthesis of DCM-OH}

DCM (1.0 g, $4.8 \mathrm{mmol})$ and 4-hydroxybenzaldehyde (704 mg, $5.8 \mathrm{mmol})$ were dissolved in toluene $(30 \mathrm{~mL})$ along with acetic acid $(0.5 \mathrm{~mL})$ and piperidine $(1.0 \mathrm{~mL})$, the system was under argon protection and then refluxed for $10 \mathrm{~h}$. Toluene was removed by evaporation, and the residue was purified by silica gel chromatography with dichloromethane to get the desired product DCM-OH $(900 \mathrm{mg}, 2.9 \mathrm{mmol})$, a dark orange solid. Yield was $60 \%$. ${ }^{1} \mathrm{H}$ NMR(400 MHz, DMSO- $\left.d_{6}, \mathrm{ppm}\right): \delta=6.85(\mathrm{~d}, J=8.8 \mathrm{~Hz}, 2 \mathrm{H}), 6.96(\mathrm{~s}, 1 \mathrm{H}), 7.28(\mathrm{~d}, J=16.0 \mathrm{~Hz}, 1 \mathrm{H}), 7.60(\mathrm{~m}$, $3 \mathrm{H}), 7.70(\mathrm{~d}, J=16.0 \mathrm{~Hz}, 1 \mathrm{H}), 7.79(\mathrm{~d}, J=7.6 \mathrm{~Hz}, 1 \mathrm{H}), 7.91(\mathrm{~m}, 1 \mathrm{H}), 8.73\left(\mathrm{dd}, J_{1}=8.4 \mathrm{~Hz}, J_{2}=1.2 \mathrm{~Hz}, 1 \mathrm{H}\right)$, 
$10.16(\mathrm{~s}, 1 \mathrm{H}) .{ }^{13} \mathrm{C} \mathrm{NMR}\left(100 \mathrm{MHz}, \mathrm{DMSO}-d_{6}, \mathrm{ppm}\right): \delta=64.27,110.96,121.15,121.26,121.30,122.35,122.65$, $124.25,129.84,131.33,135.59,140.53,144.51,157.26,158.15,164.14,165.25$. Mass spectrometry (ESI negative ion mode for $\left.[\mathrm{M} \mathrm{-} \mathrm{H}]^{-}\right)$: Calcd. for $\mathrm{C}_{20} \mathrm{H}_{11} \mathrm{~N}_{2} \mathrm{O}_{2}$ : 311.0821; found: 311.0820 .

\section{Synthesis of DCM- $\beta$ galAc}

DCM-OH (150 mg, $0.48 \mathrm{mmol}), \mathrm{Na}_{2} \mathrm{SO}_{4}(171.8 \mathrm{mg}, 1.21 \mathrm{mmol})$ and $\mathrm{Cs}_{2} \mathrm{CO}_{3}(793 \mathrm{mg}, 2.43 \mathrm{mmol})$ were dissolved in acetonitrile $(15 \mathrm{~mL})$, and then tetra- $O$-acetyl- $\alpha$ - $D$-galactopyranosyl-1-bromide $(297 \mathrm{mg}, 0.72 \mathrm{mmol})$ was added into the solution, the system was stirred at room temperature for $16 \mathrm{~h}$ under argon protection. After reaction was over, filtration was performed. The solvent was removed under reduced pressure, and the residue was taken up in sat. $\mathrm{NH}_{4} \mathrm{Cl}$, next extracted with $\mathrm{CH}_{2} \mathrm{Cl}_{2}$. After dried over anhydrous $\mathrm{Na}_{2} \mathrm{SO}_{4}$, the solvent was removed by evaporation again, and the crude product was purified by silica gel chromatography with dichloromethane to obtain the desired product DCM- $\beta$ galAc $(110 \mathrm{mg}, 0.17 \mathrm{mmol})$, a brown solid. Yield was 36\%. ${ }^{1} \mathrm{H}$ NMR (400 MHz, DMSO- $\left.d_{6}, \mathrm{ppm}\right): \delta=1.98(\mathrm{~s}, 3 \mathrm{H}), 2.06(\mathrm{~s}, 3 \mathrm{H}), 2.10(\mathrm{~s}, 3 \mathrm{H}), 2.16(\mathrm{~s}, 3 \mathrm{H}), 4.12(\mathrm{~d}, J=6.4 \mathrm{~Hz}, 2 \mathrm{H}), 4.49$ (s, 1 H), 5.24-5.30 (m, $1 \mathrm{H}), 5.38(\mathrm{~d}, J=4.0 \mathrm{~Hz}, 1 \mathrm{H}), 5.61(\mathrm{~d}, J=7.2 \mathrm{~Hz}, 1 \mathrm{H}), 5.82(\mathrm{~d}, J=4.8 \mathrm{~Hz}, 1 \mathrm{H}), 7.02(\mathrm{~s}, 1 \mathrm{H})$, $7.09(\mathrm{~d}, J=8.8 \mathrm{~Hz}, 2 \mathrm{H}), 7.44(\mathrm{~d}, J=16.6 \mathrm{~Hz}, 1 \mathrm{H}), 7.63(\mathrm{t}, J=7.6 \mathrm{~Hz}, 1 \mathrm{H}), 7.76(\mathrm{~d}, J=16 \mathrm{~Hz}, 1 \mathrm{H}), 7.79(\mathrm{~d}, J=$ $8.0 \mathrm{~Hz}, 2 \mathrm{H}), 7.81(\mathrm{~d}, J=7.6 \mathrm{~Hz}, 1 \mathrm{H}), 7.94(\mathrm{t}, J=7.6 \mathrm{~Hz}, 1 \mathrm{H}), 8.75(\mathrm{~d}, J=8.4 \mathrm{~Hz}, 1 \mathrm{H}) .{ }^{13} \mathrm{C} \mathrm{NMR}(100 \mathrm{MHz}$, DMSO- $\left.d_{6}, \mathrm{ppm}\right): \delta=20.81,20.86,20.91,20.99,60.49,67.71,68.75,70.61,71.01,73.48,97.66,106.90,116.35$, 117.22 , 117.58, 118.77, 119.51, 125.13, 126.64, 127.41, 130.43, 135.90, 138.54, 139.08, 152.51, 153.43, 158.42, $158.78,169.69,170.01,170.31,170.43$. Mass spectrometry (ESI positive ion mode for $[\mathrm{M}+\mathrm{Na}]^{+}$): Calcd. for $\mathrm{C}_{34} \mathrm{H}_{30} \mathrm{~N}_{2} \mathrm{O}_{11} \mathrm{Na}$ : 665.1747; found: 665.1751 .

\section{Synthesis of DCM- $\beta$ gal}

DCM-ßgalAc (100 mg, $0.16 \mathrm{mmol})$ was dissolved in dry methanol $(8 \mathrm{~mL})$, and sodium methylate $(54 \mathrm{mg}, 1.0$ $\mathrm{mmol})$ in dry methanol $(2 \mathrm{~mL})$ was added dropwise to the solution, and the solution was stirred for $3 \mathrm{~h}$ at room temperature. When reaction was completed, the reaction mixture was neutralized by adding Amberlite IR-120 plus $\left(\mathrm{H}^{+}\right)$until $\mathrm{pH}$ value was about 7. Purification by silica gel chromatography with dichloromethane/methanol (100:1) provided pure product DCM- $\beta$ gal $(25 \mathrm{mg}, 0.05 \mathrm{mmol})$, a dark red solid. Yield was $33 \% .{ }^{1} \mathrm{H}$ NMR $(400 \mathrm{MHz}$, DMSO- $d_{6}$, ppm): $\delta=3.51-3.72(\mathrm{~m}, 6 \mathrm{H}), 4.55(\mathrm{~d}, J=4.4 \mathrm{~Hz}, 1 \mathrm{H}), 4.69(\mathrm{t}, J=5.6 \mathrm{~Hz}, 1 \mathrm{H}), 4.91(\mathrm{~d}, J=5.6 \mathrm{~Hz}, 1$ H), $4.95(\mathrm{~d}, J=8.0 \mathrm{~Hz}, 1 \mathrm{H}), 5.22(\mathrm{~d}, J=5.2 \mathrm{~Hz}, 1 \mathrm{H}), 7.01(\mathrm{~s}, 1 \mathrm{H}), 7.12(\mathrm{~d}, J=8.4 \mathrm{~Hz}, 2 \mathrm{H}), 7.41(\mathrm{~d}, J=16.0 \mathrm{~Hz}$, $1 \mathrm{H}), 7.63(\mathrm{t}, J=7.6 \mathrm{~Hz}, 1 \mathrm{H}), 7.75(\mathrm{~d}, J=8.8 \mathrm{~Hz}, 2 \mathrm{H}), 7.76(\mathrm{~d}, J=15.2 \mathrm{~Hz}, 1 \mathrm{H}), 7.81(\mathrm{~d}, J=8.4 \mathrm{~Hz}, 1 \mathrm{H}), 7.94$ (t, $J=7.6 \mathrm{~Hz}, 1 \mathrm{H}), 8.75(\mathrm{~d}, J=8.0 \mathrm{~Hz}, 1 \mathrm{H}) .{ }^{13} \mathrm{C}$ NMR $\left(100 \mathrm{MHz}, \mathrm{DMSO}-d_{6}, \mathrm{ppm}\right): \delta=60.12,60.84,68.60$, $70.66,73.72,76.08,101.00,106.69,116.43,117.14,117.58,117.77,118.03,119.54,125.11,126.62,129.08$, 130.35, 135.87, 139.01, 152.51, 153.43, 159.01, 159.76. Mass spectrometry (ESI positive ion mode for $\left.[\mathrm{M}+\mathrm{Na}]^{+}\right)$: Calcd. for $\mathrm{C}_{26} \mathrm{H}_{22} \mathrm{~N}_{2} \mathrm{O}_{7} \mathrm{Na}$ : 497.1325; found: 497.1320.

\section{In vitro enzymatic assay}


DCM- $\beta$ gal was used at a final concentration of $10 \mu \mathrm{M}$. Absorption and fluorescence spectra of DCM- $\beta$ gal with $\beta$-gal enzymatic reactions were performed at $37{ }^{\circ} \mathrm{C}$ in a $2 \mathrm{~mL}$ total volume of PBS buffer $(0.1 \mathrm{M}, \mathrm{pH} 7.4,30 \%$ DMSO) in a $1 \mathrm{~cm}$ cuvette.

\section{Cell experiment}

\section{Cell lines}

Human embryonic kidney 293 T cells was supplied by the Institute of Cell Biology (Shanghai, China). 293T cells were cultured at $37^{\circ} \mathrm{C}$ under a humidified 5\% $\mathrm{CO}_{2}$ atmosphere in DMEM (GIBCO/Invitrogen, Camarillo, CA, USA), which were supplemented with $10 \%$ fetal bovine serum (FBS, Biological Industry, Kibbutz Beit Haemek, Israel) and $1 \%$ penicillin-streptomycin $\left(10,000 \mathrm{U} \mathrm{mL}^{-1}\right.$ penicillin and $10 \mathrm{mg} / \mathrm{mL}$ streptomycin, Solarbio life science, Beijing, China). LacZ gene was introduced into 293T cells to obtain lacZ-(+) 293T cells by gene transfection method according standard protocol.

Human ovarian cancer OVCAR-3 cells was supplied by the CoBioer biosciences Co., Ltd (Nanjing, China). OVCAR-3 cells were cultured at $37{ }^{\circ} \mathrm{C}$ under a humidified $5 \% \mathrm{CO}_{2}$ atmosphere in RPMI-1640 medium (GIBCO/Invitrogen, Camarillo, CA, USA), which were supplemented with $10 \%$ fetal bovine serum (FBS, Biological Industry, Kibbutz Beit Haemek, Israel) and 1\% penicillin-streptomycin $\left(10,000 \mathrm{U} \mathrm{mL}^{-1}\right.$ penicillin and $10 \mathrm{mg} / \mathrm{mL}$ streptomycin, Solarbio life science, Beijing, China).

\section{LacZ gene transient transfection}

$293 \mathrm{~T}$ cells were centrifuged and resuspended in fresh serum-free DMEM at a density of $1.0 \times 10^{6} \mathrm{cells}_{\mathrm{mL}}^{-1}$ before transfection. $500 \mu \mathrm{L}$ cell suspension was distributed per well in a 12 -well plate. DNA was diluted in fresh serum-free DMEM (in a volume equivalent to one-tenth of the culture to be transfected), PEI was added, and the mixture immediately vortexed and incubated for $10 \mathrm{~min}$ at room temperature prior to its addition to the cells. Following a $3 \mathrm{~h}$ incubation with DNA-PEI complexes, culture medium was completed to $1 \mathrm{~mL}$ by the addition of DMEM supplemented with $10 \%$ FBS.

\section{In vitro cytotoxicity assay}

The cytotoxicity of DCM- $\beta$ gal or DCM-OH towards $293 \mathrm{~T}$ and OVCAR-3 cell lines was measured by 3-(4, 5-dimethylthiazol-2-yl)-2, 5-diphenyltetrazolium bromide (MTT) assay. The cytotoxicity was evaluated by Cell Counting Kit-8 (Dojindo, Tokyo, Japan) according to the factory's instruction. Cells were plated in 96-well plates 
in $0.1 \mathrm{~mL}$ volume of DMEM or RPMI1640 medium with $10 \% \mathrm{FBS}$, at a density of $1 \times 10^{4}$ cells/well and added with desired concentrations of DCM- $\beta$ gal or DCM-OH (0.1\% DMSO). After incubation for $24 \mathrm{~h}$, absorbance was measured at $450 \mathrm{~nm}$ with a Genios multifunction-reader (Tecan GENios Pro, Tecan Group Ltd. Maennedorf, Switzerland). Each concentration was measured in triplicate and used in three independent experiments.

\section{Animals}

Ethics statement Animal procedures were performed in accordance with the recommendations in the Guide for the Care and Use of Laboratory Animals published by the National Institutes of Health. The animal study was approved by the Institutional Animal Care and Use Committees of the China Medical Association (Permit Number: CCMA 2012-2397). The 6-week-old BALB/c homozygous athymic nude mice which weight was about 23 g were purchased from Shanghai Slac Laboratory Animal Company, and raised in the standard conditions. The animals were kept in specific pathogen-free environment with a 12-h light/12-h dark schedule and housed in sterile cages with airflow hoods. They were fed with autoclaved chow and water randomly.

\section{Real-time in vivo imaging in tumor-bearing mice}

The nude mice were inoculated with a colorectal cancer cell LoVo on their right flanks by injecting $10^{6}$ cells subcutaneously. Diameter of tumors is $c a .1 \mathrm{~cm}$. Avidin- $\beta$-gal $(100 \mu \mathrm{g})$ in PBS was intravenously injected via tail vein into the human colorectal tumor-bearing nude mice to upregulate $\beta$-gal concentration in tumors. The unpretreated tumor-bearing mice serve as control. The real-time in vivo imaging and three-dimensional (3D) in vivo imaging was recorded at different time internals (0-3 h) after DCM- $\beta$ gal injecton using PerkinElmer IVIS Lumina Kinetic Series III imaging system and IVIS Spectrum CT imaging system, respectively. The number of injected animals (nude mice) is $3 \times 10$ (parallel experiments: blank 2, intratumoral injection 6 , intravenous injection 2). The concentration of the injected solution is $0.0375 \mathrm{mg} \mathrm{kg}^{-1}(\mathrm{PBS} / \mathrm{DMSO}=95: 5, \mathrm{pH}=7.4)$. In the in vivo imaging, $\lambda_{\mathrm{ex}}=540 \pm 10 \mathrm{~nm}, \lambda_{\mathrm{em}}=710 \pm 15 \mathrm{~nm}$. In situ injection is intratumoral injection. 


\section{Absorption and fluorescence spectra of $\mathrm{DCM}^{-} \mathrm{O}^{-}$}
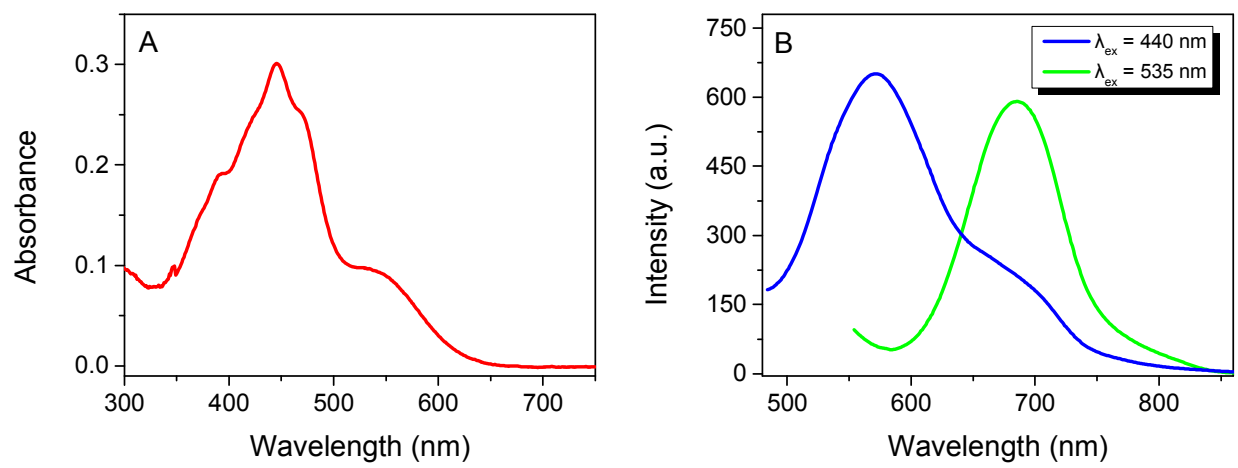

Figure S1. (A) Absorption and (B) fluorescence spectra of DCM-O ${ }^{-}(10 \mu \mathrm{M})$ in PBS/DMSO solution (7:3, v/v, pH $\left.=7.4,37^{\circ} \mathrm{C}\right)$

\section{Absorption and fluorescence spectra of DCM- $\beta$ gal incubation with $\beta$-gal}
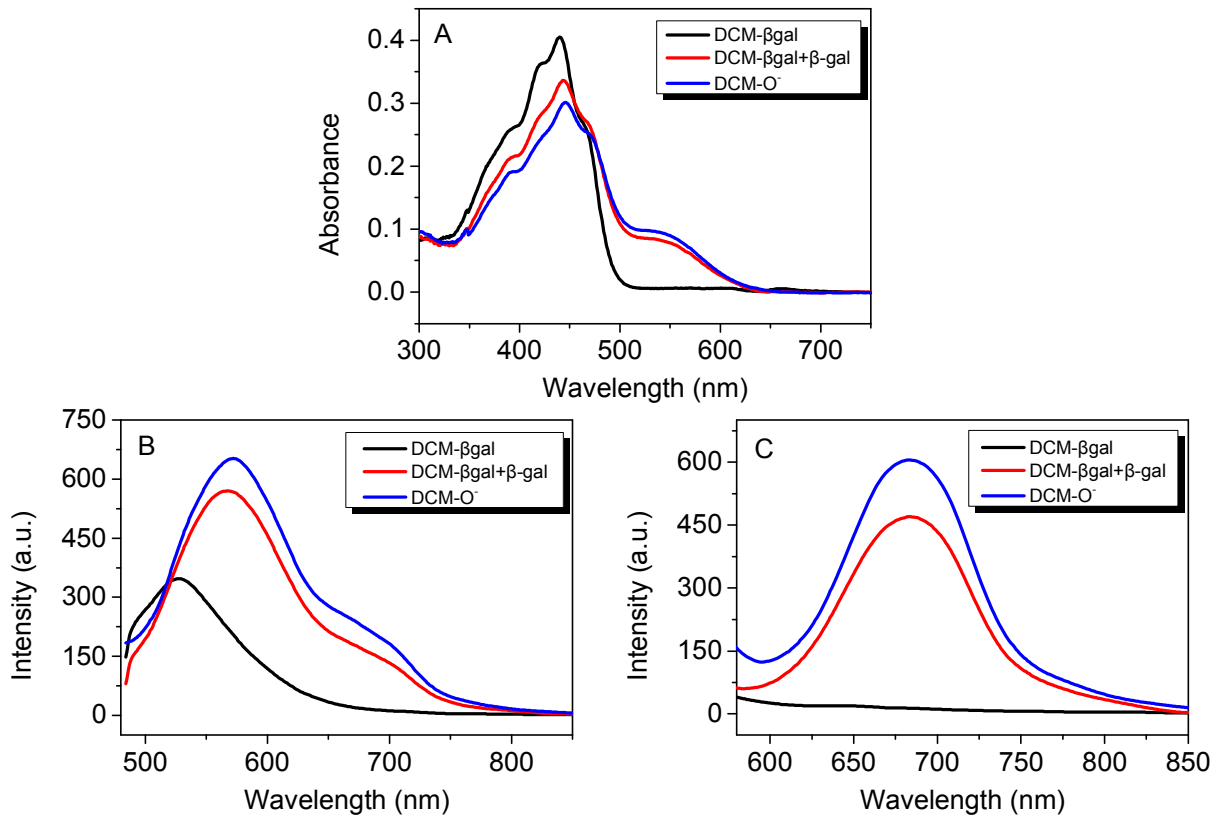

Figure S2. (A) Absorption and (B, C) fluorescence spectra of DCM- $\beta$ gal in the absence and presence of $\beta$-gal and $\mathrm{DCM}^{-} \mathrm{O}^{-}$in PBS/DMSO solution $\left(7: 3, \mathrm{v} / \mathrm{v}, \mathrm{pH}=7.4,37^{\circ} \mathrm{C}\right)$. Note: Excitation wavelength of $\mathrm{B}$ is $450 \mathrm{~nm}$; excitation wavelength of $\mathrm{C}$ is $535 \mathrm{~nm}$. 


\section{Kinetics curve of DCM- $\beta$ gal reaction with $\beta$-gal at $685 \mathrm{~nm}$}

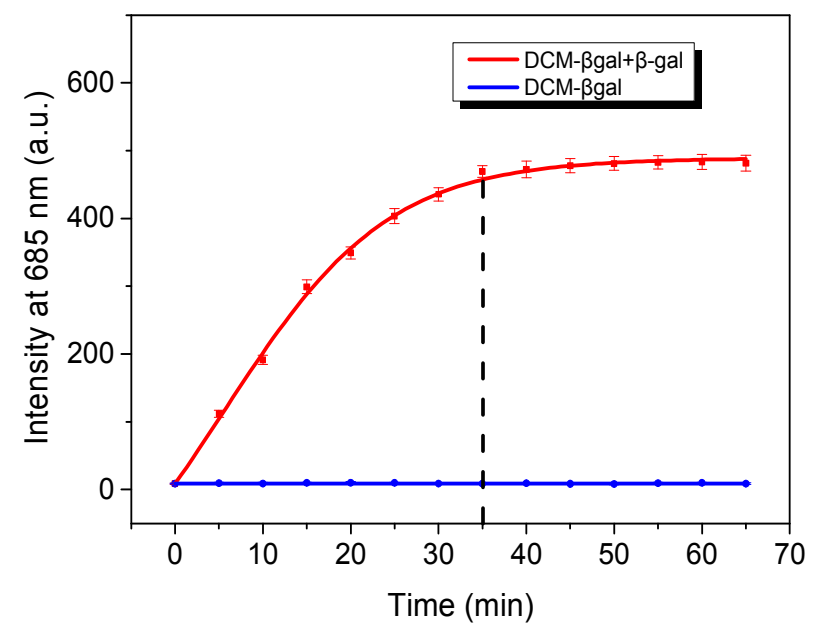

Figure S3. Time dependence of fluorescence intensity at $685 \mathrm{~nm}$ for DCM- $\beta$ gal $(10 \mu \mathrm{M})$ in PBS/DMSO solution (7:3, v:v, $\mathrm{pH}=7.4,37^{\circ} \mathrm{C}$ ) in the presence (red) and absence (blue) of $\beta$-gal. $\lambda_{\mathrm{ex}}=535 \mathrm{~nm}$. 


\section{Photophysical properties of DCM- $\beta$ gal, DCM-O ${ }^{-}$, and DCM-OH}

Table S1 Photophysical Properties of DCM- $\beta$ gal, DCM-O ${ }^{-}$, and DCM-OH

\begin{tabular}{lllll}
\hline & $\Phi_{\mathrm{F}}{ }^{\mathrm{a}}$ & $\varepsilon\left(\mathrm{L} \mathrm{mol}^{-1} \mathrm{~cm}^{-1}\right)$ & $\tau(\mathrm{ns})$ & $\chi^{2}$ \\
\hline DCM- $\beta$ gal & 0.01 & $4.05 \times 10^{4}$ & 0.99 & 1.157 \\
DCM-O $^{-}$ & 0.58 & $3.38 \times 10^{4}$ & 1.37 & 1.265 \\
DCM-OH & 0.05 & $3.23 \times 10^{4}$ & 1.38 & 1.308 \\
\hline
\end{tabular}

${ }^{\text {a }}$ The relative fluorescence quantum yield $\Phi_{\mathrm{F}}$ value was determined using fluorescein as a reference

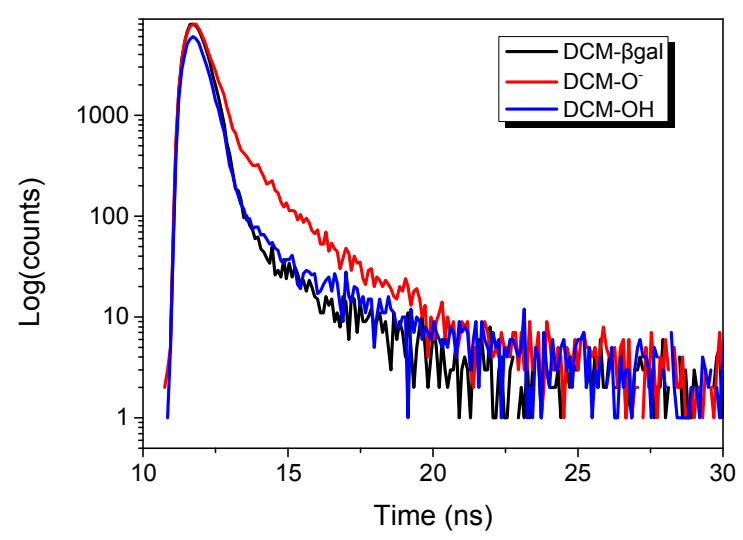

Fluorescence decay of DCM- $\beta$ gal, DCM-O - , and DCM-OH. $\lambda_{\mathrm{ex}}=447 \mathrm{~nm}, \lambda_{\mathrm{em}}=525 \mathrm{~nm}$. 


\section{Enzyme kinetics parameters of DCM- $\beta$ gal and $X$-gal}

Table S2. Enzyme Kinetics Parameters of DCM- $\beta$ gal and $X$-gal

\begin{tabular}{ccccc}
\hline substrate & $\begin{array}{c}K_{\mathrm{m}}{ }^{\mathrm{a}} \\
(\mu \mathrm{M})\end{array}$ & $\begin{array}{c}V_{\max } \\
\left(\mu \mathrm{M} \mathrm{s}^{-1}\right)\end{array}$ & $\begin{array}{c}K_{\text {cat }} \\
\left(\mathrm{s}^{-1}\right)\end{array}$ & $\begin{array}{c}K_{\text {cat }} / K_{\mathrm{m}} \\
\left(\mathrm{s}^{-1} \mu \mathrm{M}^{-1}\right)\end{array}$ \\
\hline DCM- $\beta$ gal & 60.07 & 0.54 & 29.19 & 0.48 \\
$X$-gal & 260.58 & 0.04 & 2.16 & $8.29 \times 10^{-3}$
\end{tabular}

${ }^{\text {a }} K_{\mathrm{m}}$ is Michealis constant, obtained from Michaelis-Menten equation $\left(V=V_{\max }[S] /\left(K_{\mathrm{m}}+[\mathrm{S}]\right)\right.$, where $V$ is initial velocity, $V_{\max }$ is maximum velocity, $[S]$ is substrate concentration, and $K_{\mathrm{m}}$ is Michealis constant).

\section{The detection limit of DCM- $\beta$ gal}

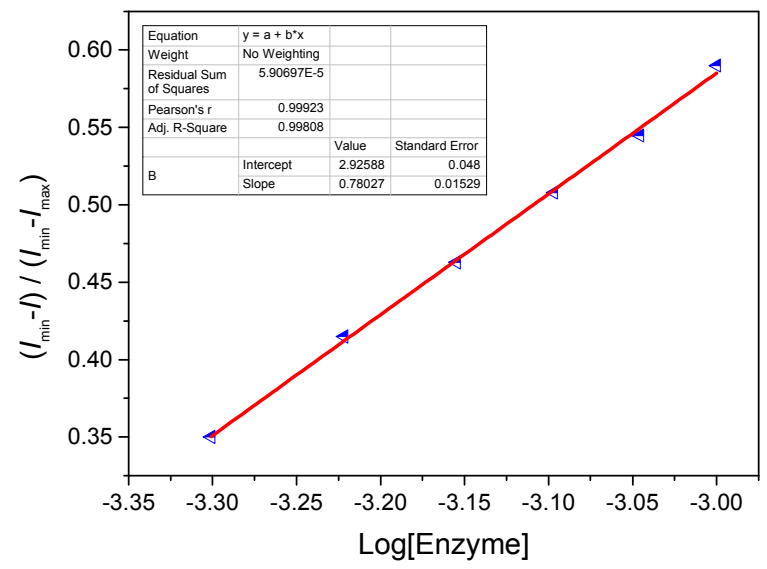

Figure S4. Fluorescence intensity ratio changes with the concentration of $\beta$-gal. Note: the detection limit was calculated based on the fluorescence titration. The limit of detection for $\beta$-gal is $1.7 \times 10^{-4} \mathrm{U} / \mathrm{mL}$. 


\section{HPLC chromatogram of DCM- $\beta$ gal and DCM-O-}

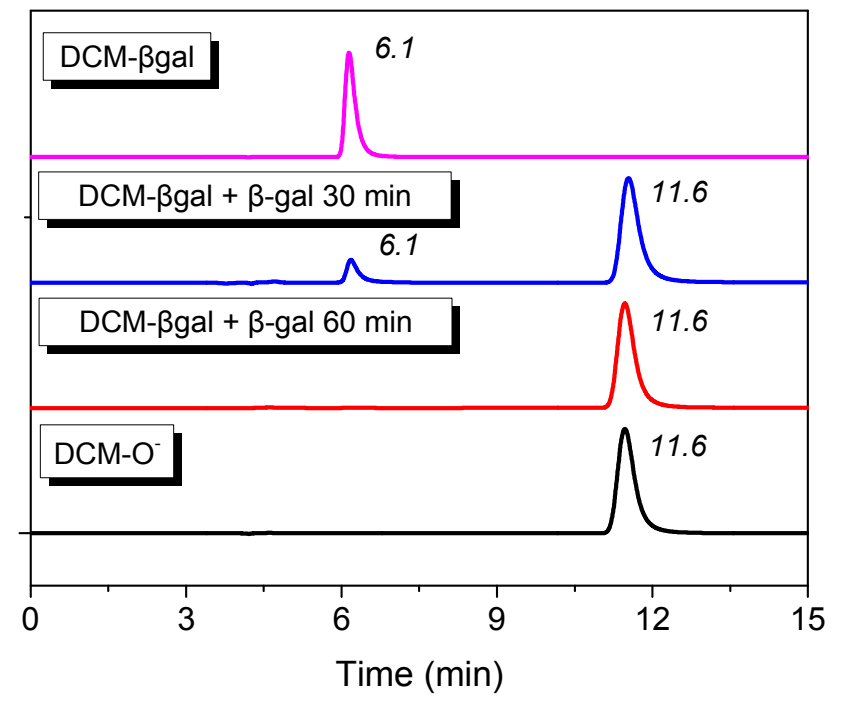

Figure S5. HPLC chromatogram of DCM- $\beta$ gal before and after 30 and 60 min reaction with $\beta$-gal, and DCM-O ${ }^{-}$ Eluent solvent: methanol/ $\mathrm{H}_{2} \mathrm{O}(\mathrm{v}: \mathrm{v}, 8: 2)$, flow rate $=0.6 \mathrm{~mL} \mathrm{~min}^{-1}$, detection wavelength at $450 \mathrm{~nm}$. 


\section{ESI-MS spectra characterization of DCM- $\beta$ gal reaction with $\beta$-gal}

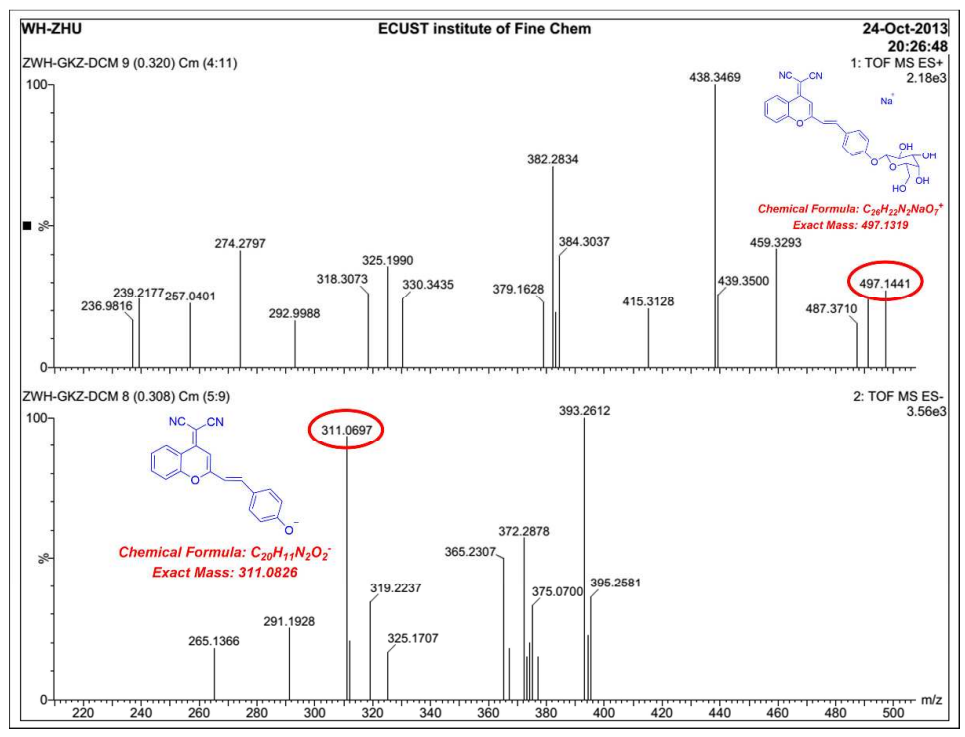

Figure S6. ESI-MS spectra characterization of DCM- $\beta$ gal reaction with $\beta$-gal. 


\section{0. pH-dependent fluorescence intensity of DCM-ßgal and DCM-OH}

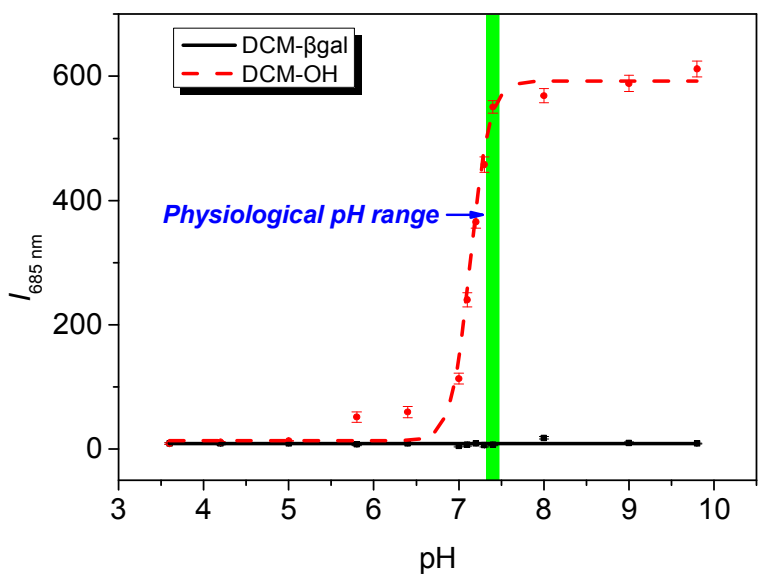

Figure S7. pH-dependent fluorescence intensity of DCM- $\beta$ gal and DCM-OH (10 $\mu \mathrm{M}$ in citrate phosphate buffer, PBS, and glycine- $\mathrm{NaOH}$ buffer solution for various $\mathrm{pH}$, monitored at $685 \mathrm{~nm}$ and $\lambda_{\mathrm{ex}}=535 \mathrm{~nm}$ ).

\section{Cytotoxicity of DCM- $\beta$ gal and DCM-OH}
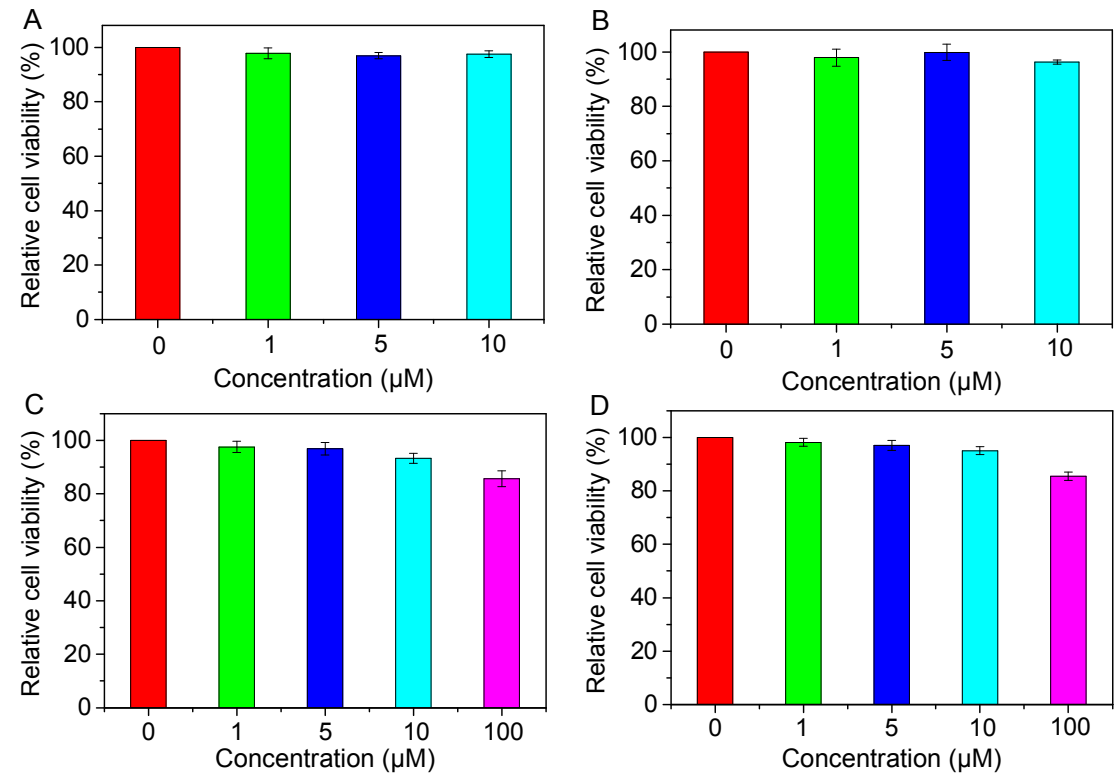

Figure S8. Relative viability of (A-B) 293T or (C-D) OVCAR-3 cells in vitro after incubation for $24 \mathrm{~h}$ with (A and C) DCM- $\beta$ gal and (B and D) DCM-OH at various concentrations. Note: both DCM- $\beta$ gal and its hydrolysate DCM-OH have minimal toxicity and enjoy superior biocompatibility toward cultured cell lines. 


\section{Semiquantitative determination of endogenous $\beta$-gal activity in living cells}

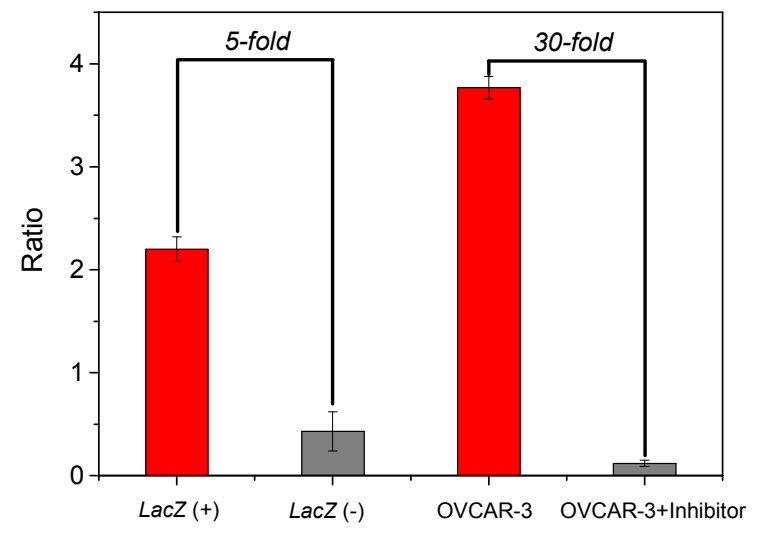

Figure S9. Semiquantitative determination of endogenous $\beta$-gal activity in lacZ-(+)/lacZ-(-) 293T cells and OVCAR-3 cells according to the ratio of averaged fluorescence intensity of red channel $(650-720 \mathrm{~nm})$ to green channel $(490-530 \mathrm{~nm})$. The semiquantitative calculation was conducted by Image Pro-plus 6.0. Error bars represent standard deviation. 


\section{In vivo imaging of $\beta$-gal activity in tumor-bearing nude mice}

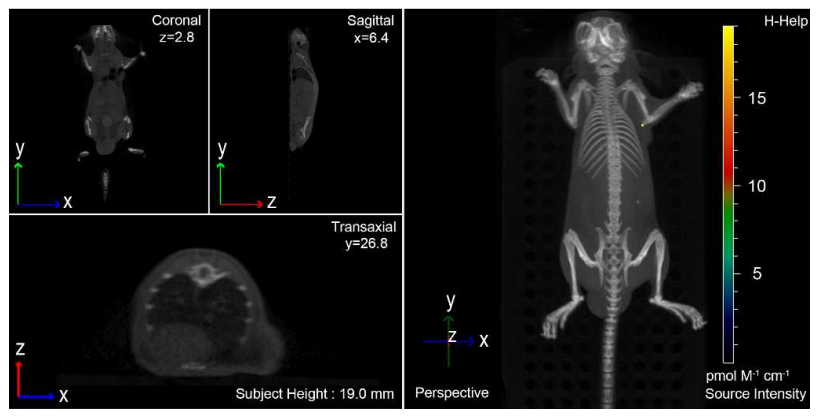

Figure S10. Three-dimensional in vivo imaging of $\beta$-gal activity in unpretreated tumor-bearing nude mice after tumor-injection of DCM- $\beta$ gal for $3 \mathrm{~h}$.

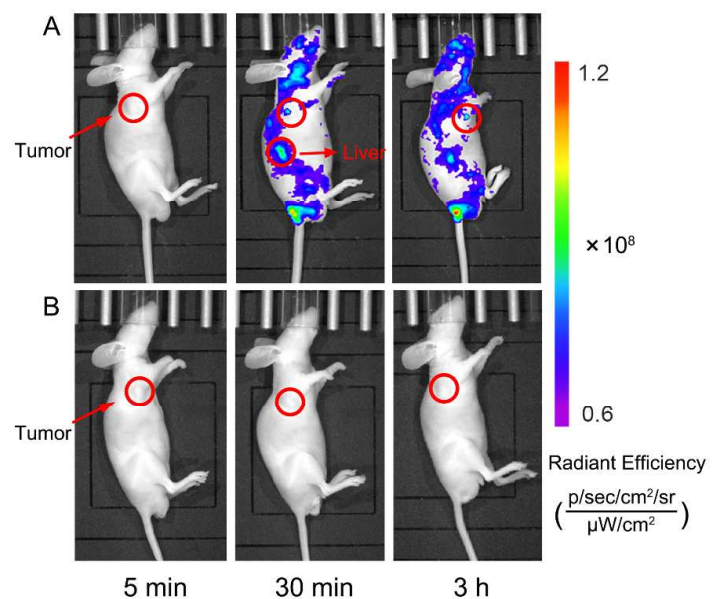

Figure S11. In vivo imaging of $\beta$-gal activity in tumor-bearing nude mice after intravenous injection: (A) avidin- $\beta$-gal $(100 \mu \mathrm{g})$ in PBS was intravenously injected into LoVo-implanted mice, and after $18 \mathrm{~h}$ DCM- $\beta$ gal was then injected into the mice, (B) tumor-bearing mice were not pretreated with avidin- $\beta$-gal before injection of DCM- $\beta$ gal acting as the control. Note: As shown in Figure S11A, after 30 min post intravenous injection, NIR fluorescent signals were captured in the tumor site and liver, which was attributed to the evolution of DCM-O ${ }^{-}$from DCM- $\beta$ gal hydrolyzed by $\beta$-gal. Dispersive fluorescent signals rather than targeted to the tumor were also observed, which may attribute that the probe lacks active-targeting ability. At $3 \mathrm{~h}$ post-injection, the NIR fluorescent signals was still founded clearly. In sharp contrast, there was no fluorescent signals for the control mice even after $3 \mathrm{~h}$ post injection. 


\section{Stereoview crystal structure of $\beta$-gal}

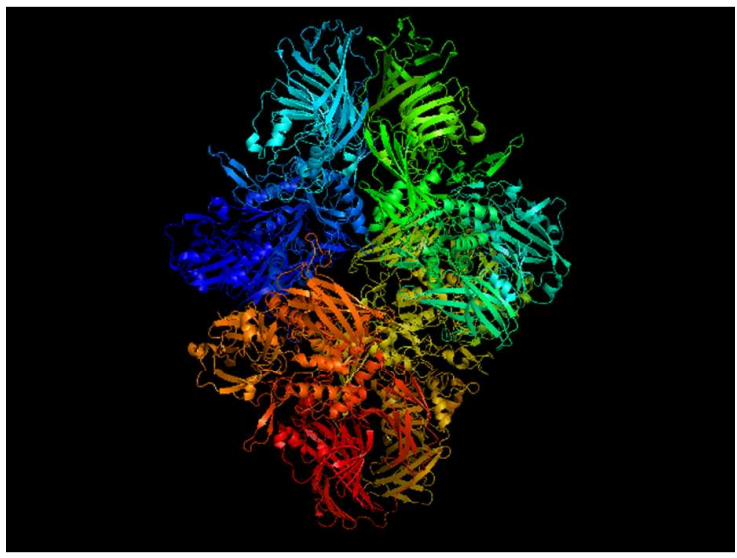

Figure S12. A stereoview crystal structure of $\beta$-gal. Note: $\beta$-gal (PDB code 3MUY) was obtained from the PDB database (http:// www.rcsb.org/pdb). The stereoview crystal structure was created by Pymol software. 
15. Characterization of intermediate compounds and DCM- $\beta$ gal

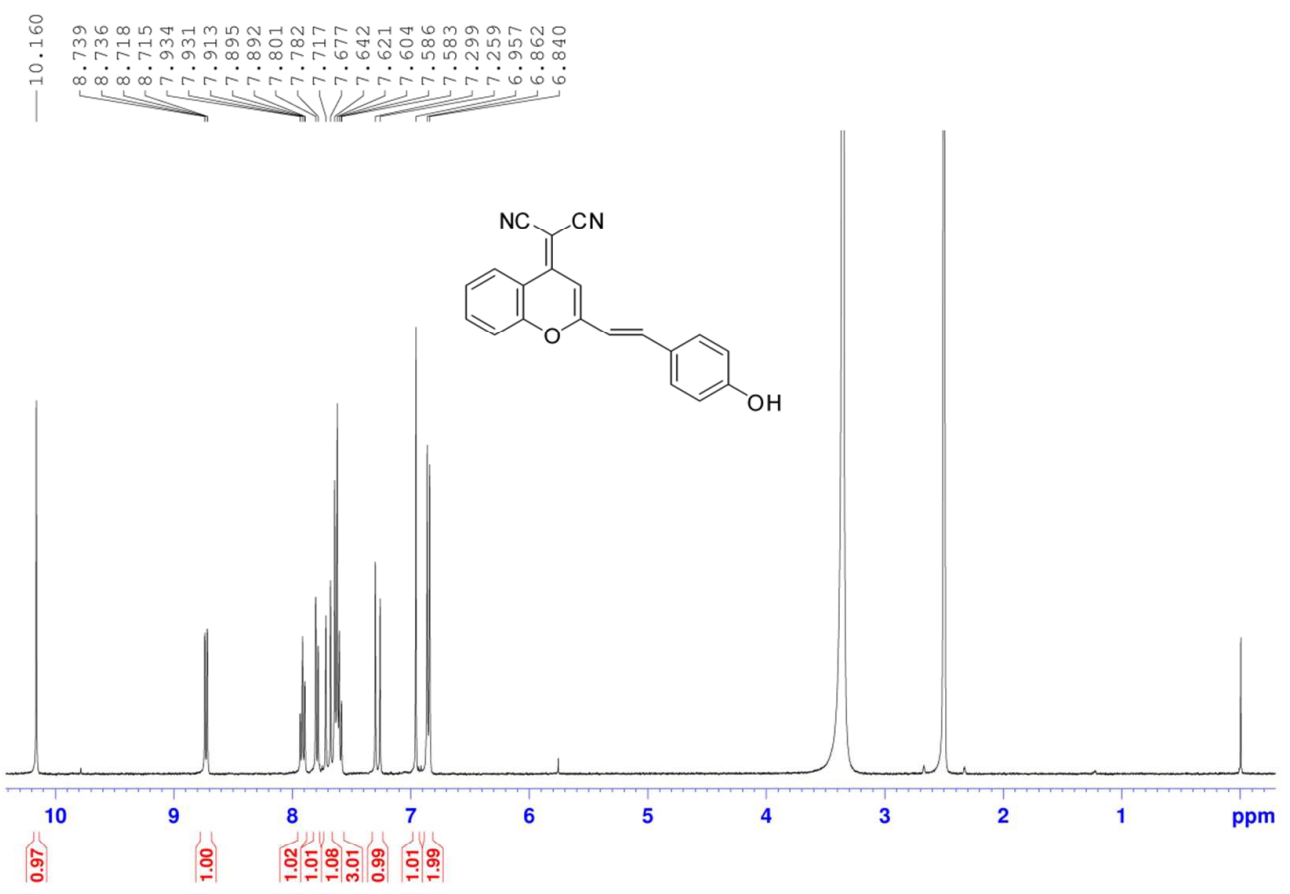

Figure S13. ${ }^{1} \mathrm{H}$ NMR spectrum of DCM-OH DMSO- $d_{6}$

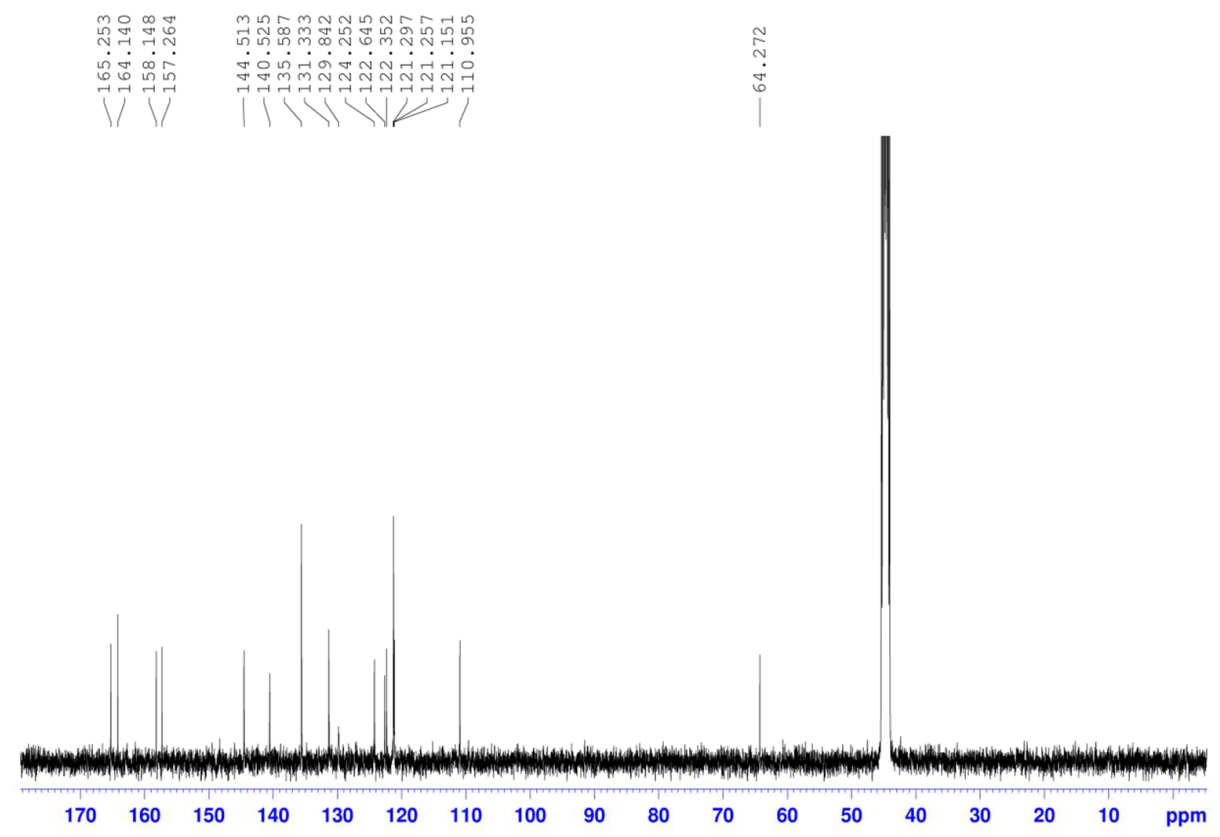

Figure S14. ${ }^{13} \mathrm{C}$ NMR spectrum of DCM-OH in DMSO- $d_{6}$ 


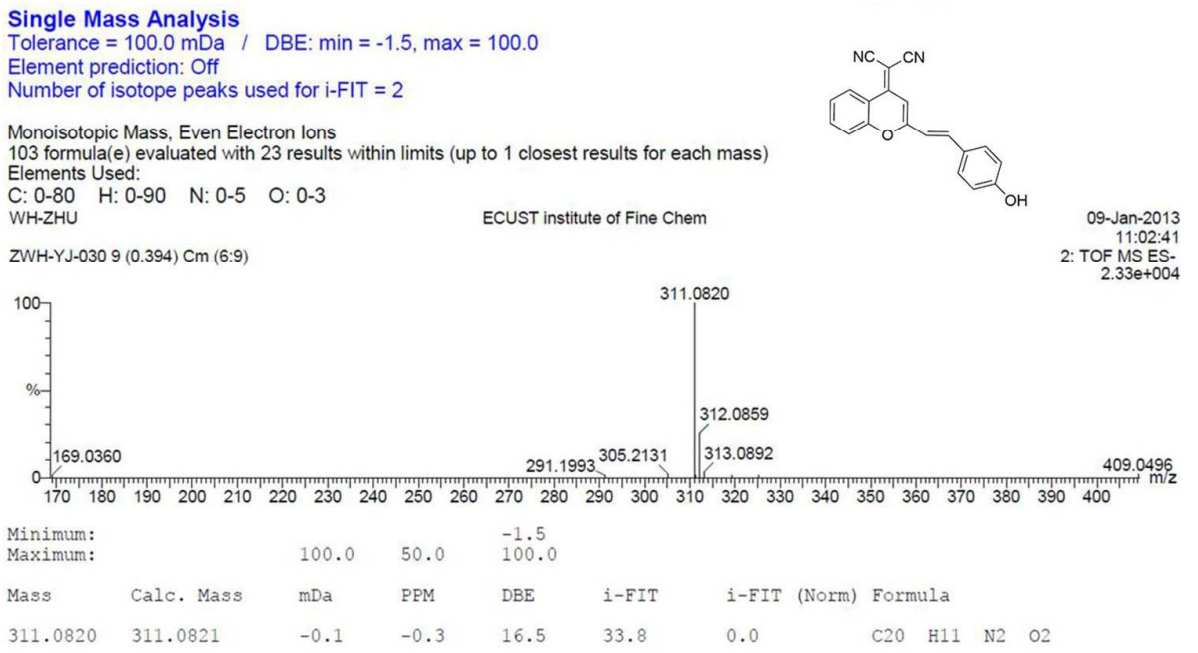

Figure S15. HRMS spectrum of DCM-OH

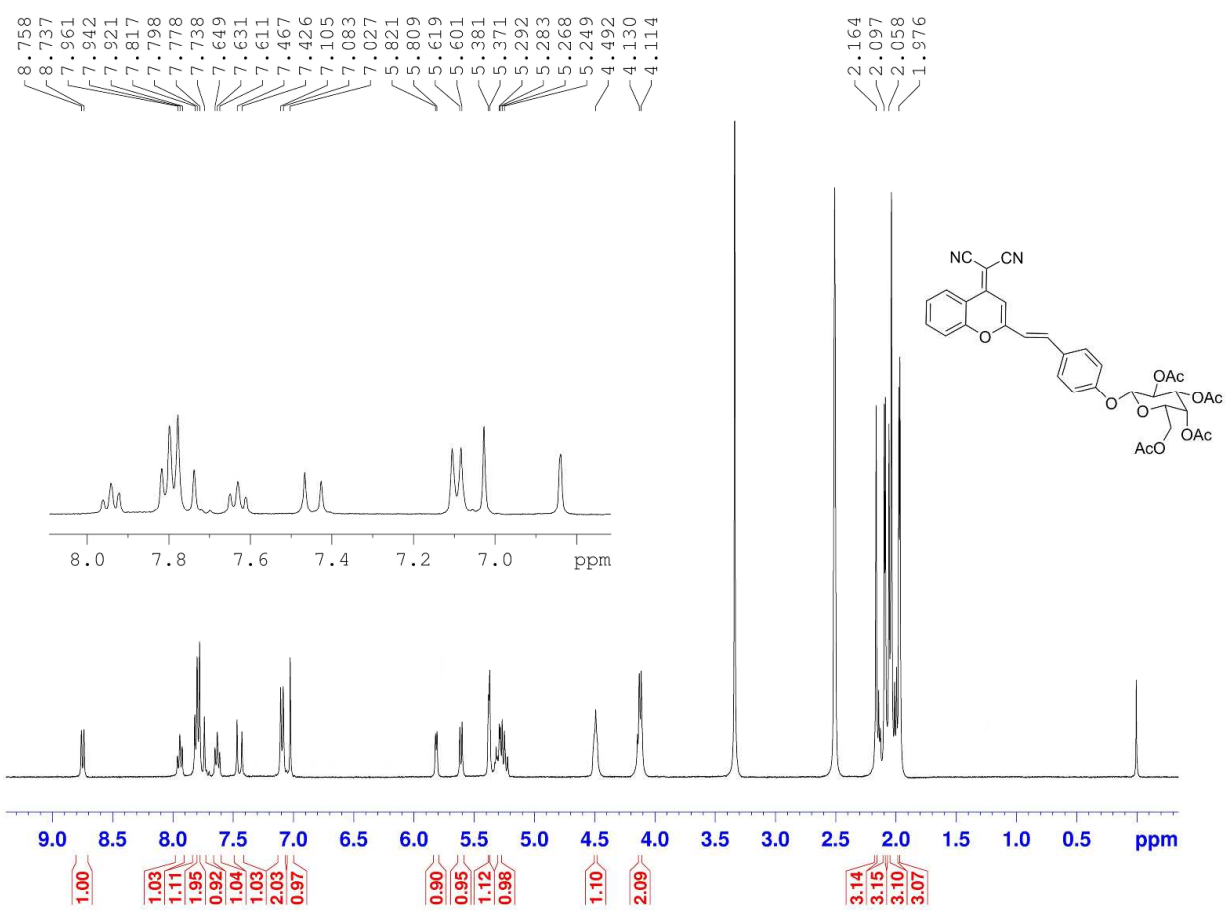

Figure S16. ${ }^{1} \mathrm{H}$ NMR spectrum of DCM- $\beta$ galAc in DMSO- $d_{6}$ 


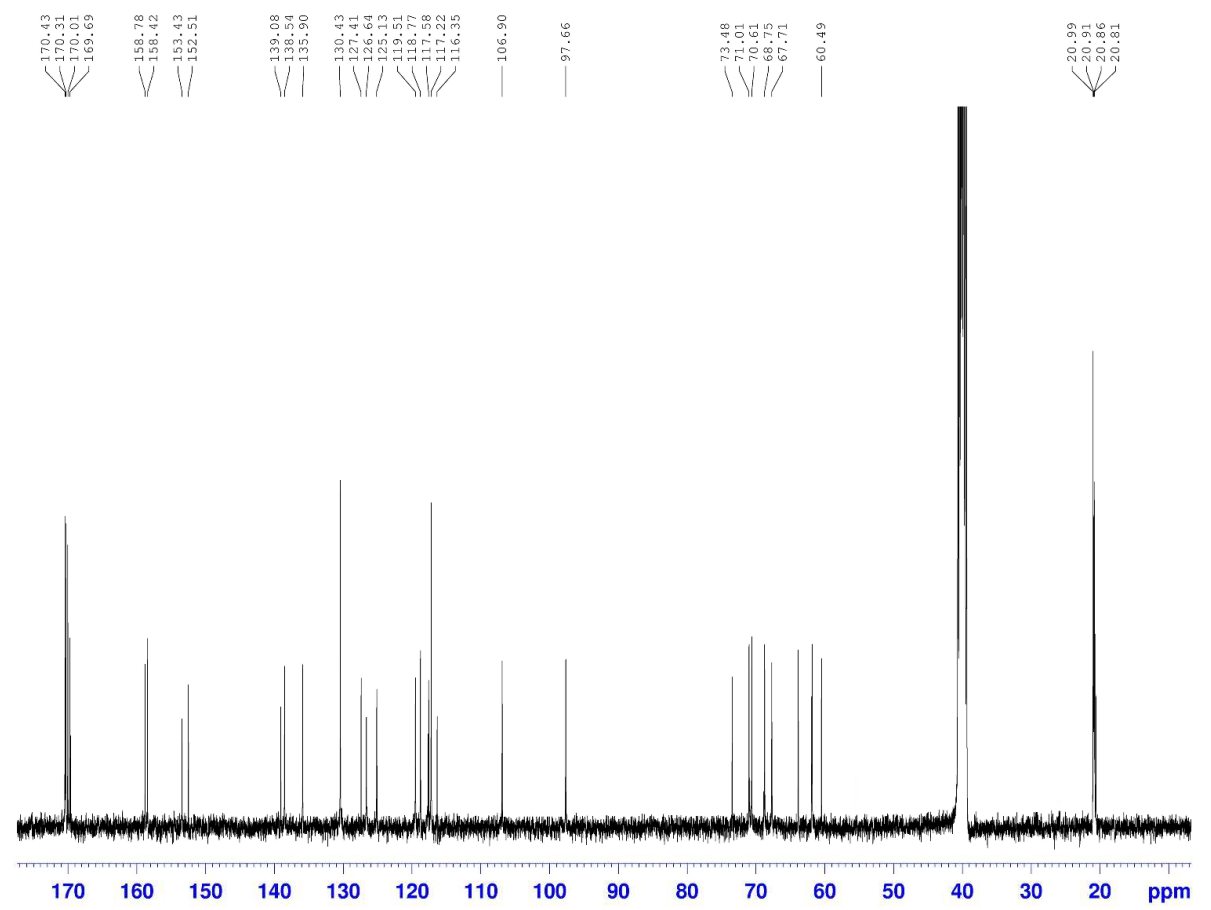

Figure S17. ${ }^{13} \mathrm{C}$ NMR spectrum of DCM- $\beta$ galAc in DMSO- $d_{6}$

$\mathrm{S}$ ing le $\mathrm{M}$ as $\mathrm{A}$ nalys is

Tolerance $=30.0 \mathrm{mDa} /$ DBE: $\min =-1.5, \max =100.0$

Element prediction: Off

Number of isotope peaks used for i-FIT $=2$

Monoisotopic Mass, Even Electron lons

628 formula(e) evaluated with 32 results within limits (up to 1 closest results for each mass)

Elements Used:

$\begin{array}{lllll}\text { C: } 0-40 & \mathrm{H}: 0-80 & \mathrm{~N}: 0-4 & \mathrm{O}: 0-15 & \mathrm{Na}: 0-1\end{array}$

WH-ZHU

ECUST institute of Fine Chem

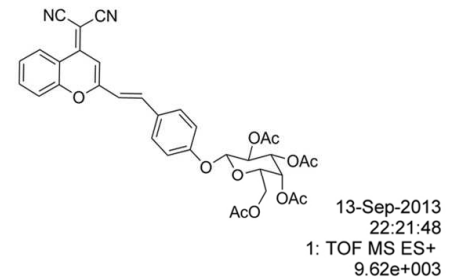

ZWH-GKZ-0913 38 (0.328) Cm (29:64)

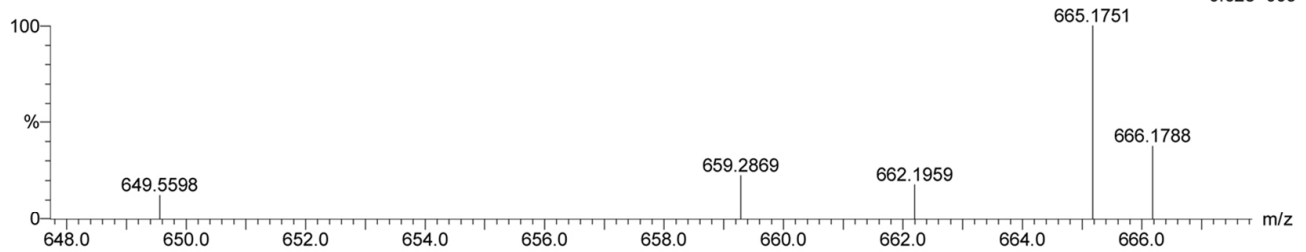

Minimum:

Maximum:

$\begin{array}{lll}30.0 & -1.5 \\ & 50.0 & 100.0\end{array}$

Mass

Calc. Mass $\mathrm{mDa}$

PPM

DBE

i-FIT

i-EIT (Norm) Formula

665.1751

665.1747

$0.4 \quad 0.6$

20.5

23.0

0.0

$\begin{array}{lllll}\text { C34 } & \mathrm{H} 30 & \mathrm{~N} 2 & \mathrm{O} 11 & \mathrm{Na}\end{array}$

Figure S18. HRMS spectrum of DCM- $\beta$ galAc 


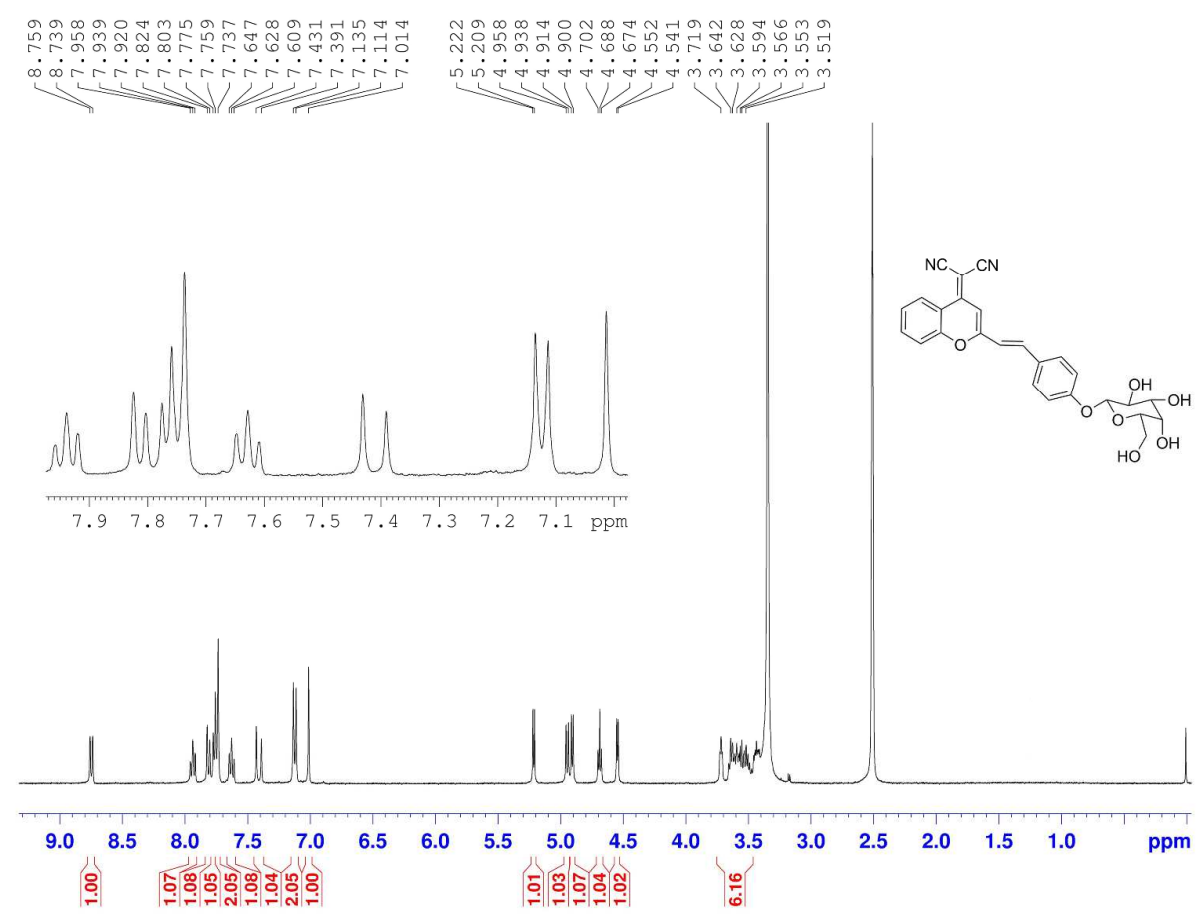

Figure S19. ${ }^{1} \mathrm{H}$ NMR spectrum of DCM- $\beta$ gal in DMSO- $d_{6}$

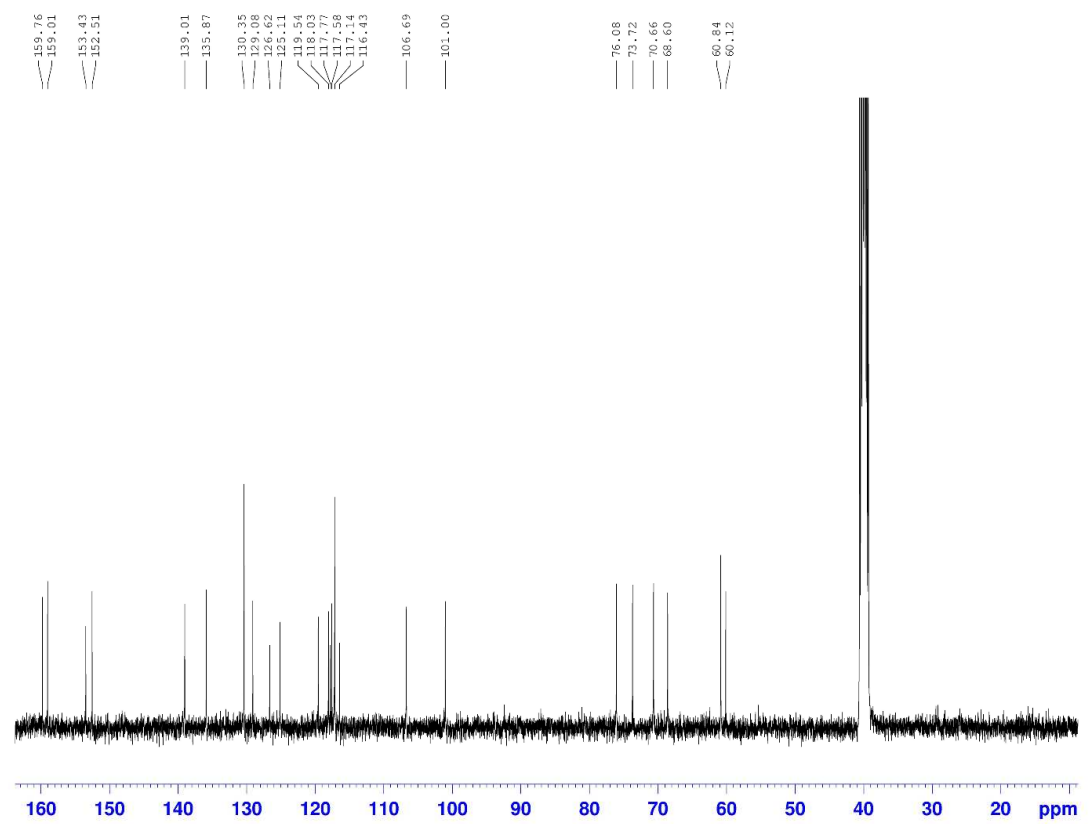

Figure S20. ${ }^{13} \mathrm{C}$ NMR spectrum of DCM- $\beta$ gal in DMSO- $d_{6}$ 
$\mathrm{S}$ ing le $\mathrm{M}$ ass Analys is

Tolerance $=30.0 \mathrm{mDa} \quad /$ DBE: $\min =-1.5, \max =100.0$

Element prediction: Off

Number of isotope peaks used for i-FIT $=2$

Monoisotopic Mass, Even Electron lons

312 formula(e) evaluated with 13 results within limits (up to 1 closest results for each mass)

Elements Used:

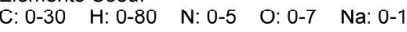

WH-ZHU ECUST institute of Fine Chem

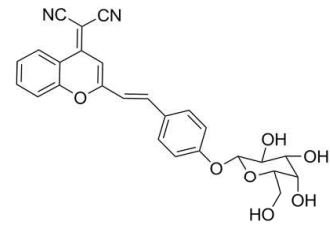

ZW-GKZ-8 173 (1.157) Cm (169:189)

24-Sep-2013

1: TOF MS ES+

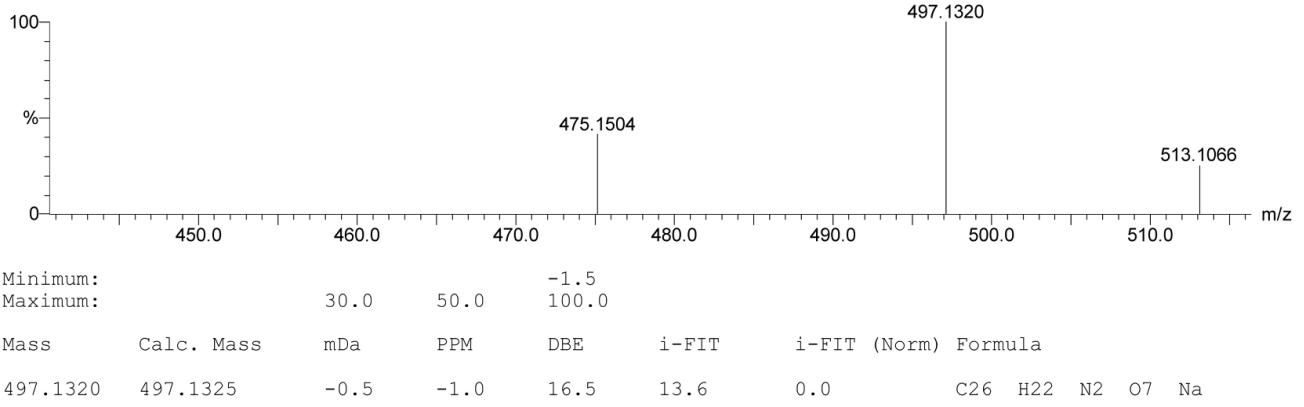

Figure S21. HRMS spectrum of DCM- $\beta$ gal 